\title{
Development of coccolithophore-based transfer functions in the western Mediterranean sea: a sea surface salinity reconstruction for the last $15.5 \mathrm{kyr}$
}

\author{
B. Ausín ${ }^{1}$, I. Hernández-Almeida ${ }^{2}$, J.-A. Flores ${ }^{1}$, F.-J. Sierro ${ }^{1}$, M. Grosjean ${ }^{2}$, G. Francés ${ }^{3}$, and B. Alonso ${ }^{4}$ \\ ${ }^{1}$ Department of Geology, University of Salamanca, Plaza de los Caídos s/n, 37008 Salamanca, Spain \\ ${ }^{2}$ Institute of Geography and Oeschger Centre for Climate Change Research, University of Bern, Erlachstrasse 9a, 3012 Bern, \\ Switzerland \\ ${ }^{3}$ Department of Marine Geosciences, University of Vigo, Campus As Lagoas - Marcosende, 36310 Vigo, Spain \\ ${ }^{4}$ Department of Marine Geosciences, Instituto de Ciencias del Mar (CSIC), Passeig Marítim de la Barceloneta, 37-49, 08003 \\ Barcelona, Spain
}

Correspondence to: B. Ausín (b_ausin@usal.es)

Received: 4 August 2015 - Published in Clim. Past Discuss.: 21 August 2015

Revised: 26 October 2015 - Accepted: 25 November 2015 - Published: 9 December 2015

\begin{abstract}
A new data set of 88 marine surface sediment samples and related oceanic environmental variables (temperature, salinity, chlorophyll $a$, oxygen, etc.) was studied to quantify the relationship between assemblages of coccolithophore species and modern environmental conditions in the western Mediterranean Sea and the Atlantic Ocean, west of the Strait of Gibraltar. Multivariate statistical analyses revealed that coccolithophore species were primarily related to sea surface salinity (SSS), explaining an independent and significant proportion of variance in the coccolithophore data. A quantitative coccolithophore-based transfer function to estimate SSS was developed using the modern analog technique (MAT) and weighted-averaging partial least square regression (WA-PLS). The bootstrapped regression coefficient $\left(R_{\text {boot }}^{2}\right)$ was $0.85_{\mathrm{MAT}}$ and $0.80_{\mathrm{WA}-\mathrm{PLS}}$, with a root-mean-square error of prediction (RMSEP) of $0.29_{\mathrm{MAT}}$ and $0.30_{\text {WA-PLS }}(\mathrm{psu}$ ). The resulting transfer function was applied to fossil coccolithophore assemblages in the highly resolved ( $\sim 65$ years) sediment core CEUTA10PC08 from the Alboran Sea (western Mediterranean) in order to reconstruct SSS for the last $25 \mathrm{kyr}$. The reliability of the reconstruction was evaluated by assessing the degree of similarity between fossil and modern coccolithophore assemblages and by a comparison of reconstructions with fossil ordination scores. Analogs were poor for the stadials associated with Heinrich events 2 and 1 and part of the Last Glacial Maximum. Good
\end{abstract}

analogs indicate a more reliable reconstruction of the SSS for the last 15.5 kyr. During this period, several millennial and centennial SSS changes were observed and associated with sea-level oscillations and variations in the Atlantic Water entering the Alboran.

\section{Introduction}

Coccolithophores are one of the major components of marine phytoplankton. They are sensitive to changes in many environmental variables, such as nutrients, temperature and salinity, and are widely used in qualitative paleoenvironmental studies (Baumann et al., 2005; Guerreiro et al., 2013, 2014). These studies provide general insight into the response of coccolithophores to environmental variables, but quantitative studies (e.g. transfer functions) allow assessing these relationships in a more rigorous and clear manner. Transfer functions are based on the calibration of the modern relationship between organisms and environmental conditions, and this information is in turn used to reconstruct past environmental variables. Different statistical approaches based on coccolithophores have been proposed in order to generate quantitative paleoreconstructions of different ecological variables. Giraudeau and Rogers (1994) used factor analyses and multiple regressions to estimate chlorophyll $a$ from coccolithophore census counts in surface sediment samples 
in the Benguela upwelling area. Several authors (Beaufort et al., 1997, 2001; Incarbona et al., 2008) have calibrated the relative abundance of the coccolithophore Florisphaera profunda in surface sediment samples with respect to primary productivity and reconstructed past variations of this parameter in the Indian and Pacific oceans and in the central Mediterranean Sea. Saavedra-Pellitero et al. (2011, 2013) used linear regression methods to derive past sea surface temperature (SST) estimates in the southeast Pacific Ocean from coccolithophore census counts and accumulation rates. Bollmann et al. (2009) and Bollmann and Herrle (2007) applied multiple linear regressions to morphometric measurements of the coccolithophore Emiliania huxleyi from globally distributed core-top and plankton samples to obtain modern and past sea surface salinity (SSS) estimates.

To date, no coccolithophore-based transfer function has been applied in the western Mediterranean Sea, a semienclosed basin situated at midlatitudes (Fig. 1a). In this region evaporation exceeds precipitation plus runoff, such that water budgets tend to be balanced by the advection of relatively less saline Atlantic water (AW) through the Strait of Gibraltar (Bèthoux, 1979). The AW flows eastward while mixing with Mediterranean water to form the Modified Atlantic Water (MAW) at the surface (100-200 m) (Millot, 1999). This distinctive feature affects the spatial distribution of some environmental parameters such as SST and SSS, leading to the development of well-defined longitudinal gradients between the Atlantic Ocean and the western Mediterranean in annual terms. In this confined basin, the estimation of changes in these environmental parameters is essential for determining Atlantic-Mediterranean water mass exchange through the Strait of Gibraltar in the past (Rohling and Bigg, 1998; Schmidt, 1998). This exchange depends on variations in the hydrological cycle, ice-volume effects, and Mediterranean circulation patterns, which have a thermohaline origin (MEDOCGROUP, 1970).

The aim of this study is to explore the potential of coccolithophores for the development of quantitative reconstructions in the western Mediterranean Sea. We study the response of coccolithophore assemblages from surface sediment samples from the Atlantic Ocean and Mediterranean Sea to environmental variables. The resulting calibration model (transfer function) for salinity was used to reconstruct SSS changes at a high resolution in the Alboran Sea (Fig. 1a) for the last $25 \mathrm{kyr}$. The reliability of the reconstruction was assessed by analysis of the similarity between fossil and modern coccolithophore assemblages and fossil ordination scores. Finally, centennial and millennial SSS changes are described, discussed, and compared with regional records of SST and organic-matter preservation.

\section{Materials and methods}

\subsection{Modern training set}

\subsubsection{Surface sediment samples}

Initially, 117 core tops located around a horizontal transect along the western Mediterranean Sea and near the Gulf of Cadiz in the Atlantic Ocean were selected. They had been retrieved at varying water depths ranging from 70 to $2620 \mathrm{~m}$ during several oceanographic surveys and were stored at the University of Vigo and at the Core Repository of the Institute of Marine Sciences (CSIC) in Barcelona. The first centimeter (or the second if the first was unavailable) of the 117 core tops was sampled, assuming that it essentially represents present-day conditions.

\subsubsection{Environmental variables}

Data on temperature (Locarnini et al., 2013), salinity (Zweng et al., 2013), chlorophyll $a$ (Boyer et al., 2013), oxygen content and saturation (García et al., 2014a), nitrate, phosphate, and silicate (García et al., 2014b) were obtained from the 2013 World Ocean Atlas (WOA13), and mixed layer depth (Monterey and Levitus, 1997), total alkalinity $\left(T_{\mathrm{ALK}}\right)$ and total dissolved inorganic carbon (DIC) (Goyet et al., 2000) for the training set sites were selected using Ocean Data View (ODV) software (Schlitzer, 2014), for a grid of $1^{\circ}$ longitude by $1^{\circ}$ latitude, using weighted averaged gridding. Similarly, data on $\mathrm{pH}$ and carbonate $\left(\mathrm{CO}_{3}^{2-}\right)$ were calculated using the "derived variable" tool of ODV software. These data have been averaged annually and seasonally (for summer and winter) from 1955 to 2012 and were selected for 10, 20, 30, 50, $75,100,125,150$, and $200 \mathrm{~m}$ water depth.

\subsection{Fossil data set}

The fossil coccolithophore data set used for the reconstruction comprises coccolithophore census counts from core CEUTA10PC08 $\left(36^{\circ} 1^{\prime} 22^{\prime \prime} \mathrm{N}, 4^{\circ} 52^{\prime} 3^{\prime \prime} \mathrm{W} ; 914 \mathrm{~m}\right.$ b.s.l. $)$, located in the Alboran Sea, previously published by Ausín et al. (2015). Fossil assemblages show a good to moderate degree of preservation. The location of this core lies under the modern path of the AW at the surface, near the Strait of Gibraltar (Fig. 1a). Sediment core chronostratigraphy was based on 15 radiocarbon ages and covered the time span from 25 to 4.5 ka calibrated BP at a $\sim 65$ years temporal resolution (Ausín et al., 2015). All dates reported in this study are given in calibrated ages BP.

\subsection{Micropaleontological analyses}

Both modern (surface sediment) and fossil (down-core) samples were prepared for coccolithophore analyses according to the techniques proposed by Flores and Sierro (1997). A polarized-light microscope at $1000 \times$ magnification was em- 


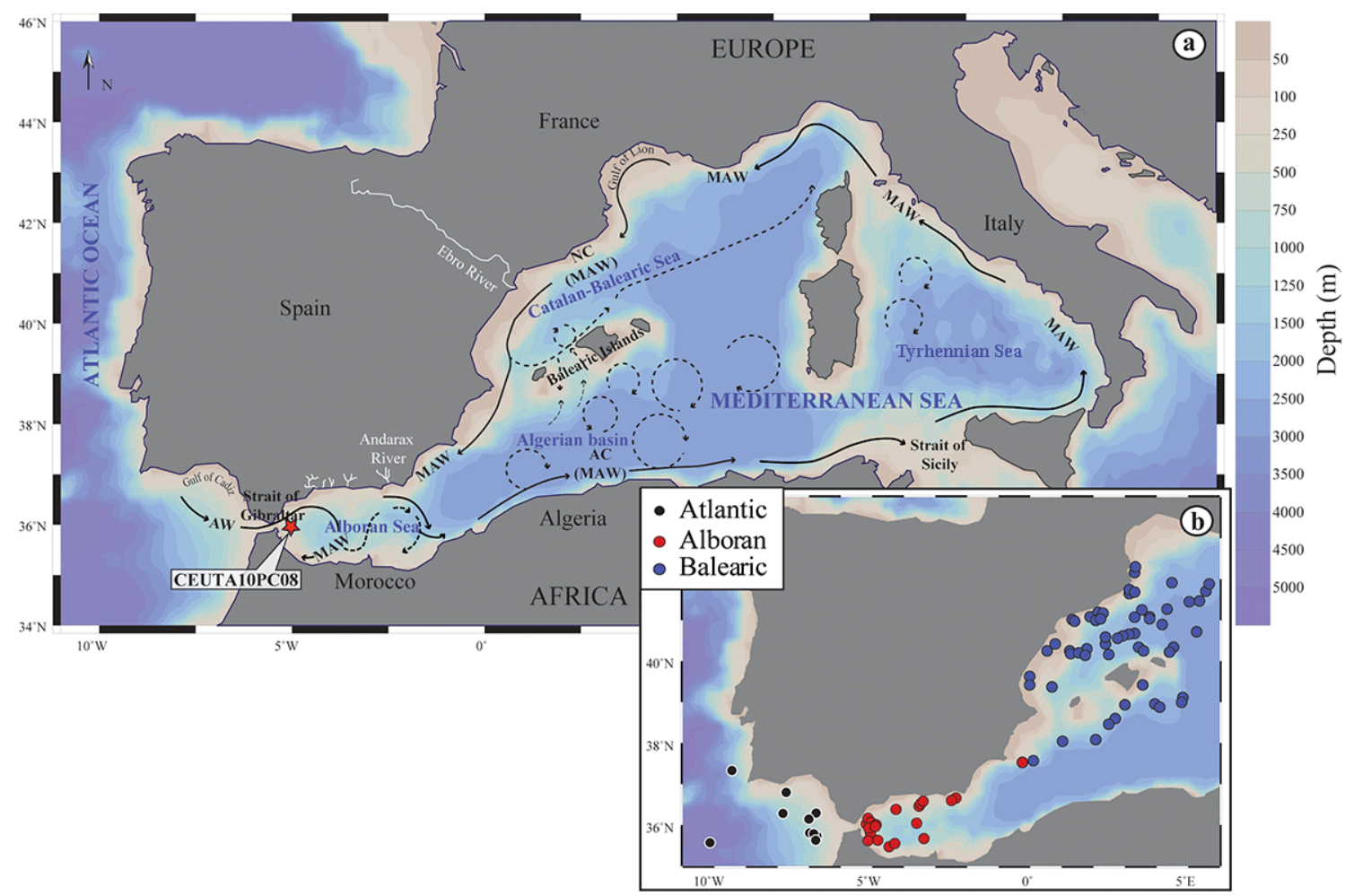

Figure 1. Maps of the study area. Panel (a): location of the CEUTA10PC08 core (red star). Black arrows trace general surface circulation. Legend: AW - Atlantic water; MAW - Modified Atlantic Water; AC - Algerian Current; NC - Northern Current. Panel (b): location of the 88 core-top samples used for final calibrations. Maps generated with Ocean Data View software (Schlitzer, 2014).

ployed to identify and count at least 500 coccoliths in each sample, belonging to 21 different taxa. Species whose relative abundance was $<1 \%$ in the first count were considered later in 20 visual fields in order to estimate their abundance accurately. The final relative abundance of each species in each sample was then recalculated. Gephyrocapsa specimens smaller than $3 \mu \mathrm{m}$ were lumped together and designated "small Gephyrocapsa" (Flores et al., 1997). The "medium Gephyrocapsa" group was made up of Gephyrocapsa whose size was between 3 and $5 \mu \mathrm{m}$. Two sizes of morphotypes of E. huxleyi $(<4$ and $>4 \mu \mathrm{m})$ were considered, owing to their different ecological and biostratigraphic significance in the study area. Similarly, G. oceanica was split according to a size criterion of $<5$ and $>5 \mu \mathrm{m}$, owing to their comparable potential ecological significance. Other taxa identified in this study were Calcidiscus leptoporus, F. profunda, Gephyrocapsa cf. caribbeanica, Gephyrocapsa muellerae, Helicosphaera spp., and Syracosphaera spp. (as dominant taxa). The rare taxa identified were Braarudosphaera bigelowii, Calciosolenia spp., Coccolithus pelagicus subsp. braarudii, Coccolithus pelagicus subsp. pelagicus, Oolithotus fragilis, Pontosphaera spp., Rhabdosphaera clavigera, Umbilicosphaera spp. and Umbellosphaera spp.

Twenty-nine samples were finally eliminated from the initial modern data set owing to their high content $(>10 \%)$ in obviously reworked nannofossils. These taxa belong to older stratigraphic levels (consistently older than the Pliocene in this study), meaning that they were resuspended and transported from their original location to the sample site, and they lack any relationship with modern environmental conditions. A maximum of $10 \%$ of reworked specimens was chosen as an acceptable threshold below which the sample could be retained in the modern training set, after ruling out these reworked specimens, without compromising the statistical representativeness of the major species (Fatela and Taborda, 2002). Later examination of the spatial distribution of reworked specimens in the retained samples revealed that those with the highest percentages were close to river mouths, relating reworked specimens to river discharges and suggesting that the rest of the assemblage could be considered autochthonous. Thus, the final training set (Supplement) comprised 88 surface samples (Fig. 1b): 78 from the western Mediterranean (58 from the Balearic Sea and 20 from the Alboran Sea) and 10 from the Atlantic Ocean. 


\subsection{Statistical analyses}

\subsubsection{Relationship between coccolithophore assemblages and environmental variables}

Prior to statistical analyses, environmental variables were checked for unimodal distribution. Only mixed layer depth, $T_{\mathrm{ALK}}$ and DIC were $\log _{10}$ transformed, since the transformation of other variables did not cause noticeable changes. Principal component analysis (PCA) was performed on this initial data set to assess the major environmental gradients and collinearity among the variables.

Coccolithophore relative abundances were square-roottransformed to stabilize their variances. The species Braarudosphaera sp., Calciosolenia spp., Coccolithus pelagicus subsp. braarudii, Coccolithus pelagicus subsp. pelagicus, and Pontosphaera spp. were excluded from the modern (and consequently from the fossil) coccolithophore assemblages since their maximum relative abundance was not $>1 \%$ in at least two samples. Detrended correspondence analysis (DCA) was then performed on the modern coccolithophore assemblage to estimate the length of the environmental gradient. A length of the first DCA axis $>2$ standard deviations (SD) indicates the unimodal responses of the organisms (Birks, 1995; ter Braak and Prentice, 1988), while shorter lengths indicate linear responses.

Akaike's information criterion (AIC) was used in an ordination analysis to identify the minimum number of variables (subset) that, being statistically significant, explained the maximum variation in the modern coccolithophore assemblage. Canonical correspondence analysis (CCA) was used to evaluate the influence of this environmental subset to explain coccolithophore distribution in the modern training set.

The ratio between the first constrained axis and the first unconstrained axis $\left(\lambda_{1} / \lambda_{2}\right)$ was used as a diagnosis to test the strength of a single environmental variable when the effects of those remaining were excluded from the analyses (ter Braak and Juggins, 1993). If $\lambda_{1} / \lambda_{2} \geq 1$, the variable under examination is considered to be important for explaining the distribution of the species. The proportion of the variance in the coccolithophore training set explained uniquely by each significant environmental variable was calculated using variance partitioning.

Ordination analyses and variance partitioning were performed using the "vegan" package v.2.3. (Oksanen et al., 2015) for R (R Core Team, 2015).

\subsubsection{Transfer function}

Calibration models were calculated for the variable of interest (and each variable by means of exploratory analysis) using the weighted-averaging partial least squares (WAPLS) method (ter Braak and Juggins, 1993; ter Braak et al., 1993) and the modern analog technique (MAT) (Prell, 1985), both implemented in the C2 version 1.4.3 software
(Juggins, 2007). All models were calculated for the crossvalidation predictions by bootstrapping ( 999 permutation cycles) (Birks, 1995). In the AT, the number of analogs resulting in the maximum coefficient of determination $\left(R_{\text {boot }}^{2}\right)$ between the observed and predicted values and the lowest root-mean-square error of prediction (RMSEP) (Telford et al., 2004) was calculated using an optimization set together with the usual training and test sets implemented in the "analog" package for R (R Core Team, 2015). In WA-PLS, a decrease of $5 \%$ or more in RMSEP was required to retain the next component (Birks, 1995; ter Braak et al., 1993).

Many coccolithophore species inhabit depths within a specific range of the photic zone and are subject to environmental seasonality (Winter et al., 1994). Therefore, the depth and season considered for calibration and reconstruction should be those that most influenced the coccolithophore fossil assemblage. Following the procedure described by Telford et al. (2013), we reconstructed the variable of interest based on summer-, winter- and annually averaged data at nine different depths of the photic zone from 10 to $200 \mathrm{~m}$ using the "paleoSig" package v.1.1-1 (Telford, 2012) for R (R Core Team, 2015). The reconstruction that explains the highest proportion statistically significant of variance in the fossil data reflects the depth and season that most influenced the coccolithophore fossil assemblage, and it hence provides the most suitable calibration.

Outliers may reduce the power of prediction of the calibration model as well as introduce undesirable effects in model coefficients (Birks, 1995). Potential outliers were determined as those whose absolute residual was higher than the mean SD of the observed values (Edwards et al., 2004).

A combination of the highest $R_{\text {boot }}^{2}$ and the lowest RMSEP was used as a criterion for the quality prediction of the model. The graphical representations of the observed values against the values predicted by the model and the residuals against the predicted values were used as a diagnosis of the model.

\subsubsection{Derived reconstruction and evaluation}

The MAT and WA-PLS were applied to the fossil coccolithophore assemblages of core CEUTA10PC08, which were previously square-root-transformed, using the $\mathrm{C} 2$ version 1.4.3 software (Juggins, 2007). Sample-specific reconstruction errors under bootstrapping were derived automatically by the $\mathrm{C} 2$ software, considering the prediction error due to (i) errors in estimating species coefficients and (ii) errors in the calibration function (further details may be found in Birks et al., 1990). In order to assess the quality of the modern analogs for the fossil (down-core) samples, the squared chord distance between each fossil sample and each sample in the modern training set (Overpeck et al., 1985) was calculated with the MAT by the C2 software. A squared chord distance below the 10th percentile would be considered good, while values above this cutoff would represent assemblages with poor analogs (Simpson, 2007). 
The first axis of the PCAs of the fossil data set ( $\left.P C 1_{\text {fossil }}\right)$ shows the most important changes in the composition of the fossil coccolithophore assemblage. Comparison between $\mathrm{PC}_{\text {fossil }}$ and the reconstructed variable of interest was used to assess whether the reconstruction could be considered representative of the major ecological changes in the fossil assemblage (Juggins, 2013).

\section{Results}

\subsection{Geographical distribution of coccolithophores}

The small placoliths (small Gephyrocapsa and E. huxleyi $<4 \mu \mathrm{m}$ ) are the dominant taxa (Fig. 2b, c) constituting on average $83 \%$ of coccolithophore assemblages. Small examples of Gephyrocapsa show higher abundances near the Spanish coast and southeast of the Balearic Islands. E. huxleyi $<4 \mu \mathrm{m}$ is more abundant in the Balearic Sea and around the Ebro River delta (Fig. 2c). G. muellerae (Fig. 2d) is concentrated southeast of the Balearic Islands and a patch of $2 \%$ appears in the northern Alboran Sea. C. leptoporus and Helicosphaera spp. (Fig. 2e, f) are almost absent in the Alboran Sea and show similar patchy distributions between the Catalan and the Balearic fronts and east of the Balearic Islands. F. profunda (Fig. $2 \mathrm{~g}$ ) is more abundant in the Atlantic Ocean (up to $16 \%$ ) and gradually decreases eastward. It appears in two patches (up to $4 \%$ ) south of the Ebro River mouth. G. oceanica ( $<5 \mu \mathrm{m})$ (Fig. $2 \mathrm{~h})$ is mostly distributed near the Strait of Gibraltar. It also appears in a patch (up to $3 \%$ ) around the Andarax River mouth.

\subsection{Relationship between coccolithophores and environmental variables}

The PC1 explains $56.1 \%$ of the variance within the environmental data set (Fig. 3a) and is highly correlated with $\mathrm{CO}_{3}^{2-}$, salinity, $\mathrm{pH}$ and $T_{\mathrm{ALK}}$. PC2 explains $22.3 \%$ of the total variance and primarily summarizes the information on temperature and phosphate.

The ordination based on the AIC revealed that only salinity, nitrate, phosphate, silicate and oxygen are needed to explain the maximum variation in the modern coccolithophore assemblage and are significant at the $95 \%$ level when added individually to the model via a forward selection procedure. The first axis of the DCA performed on the modern coccolithophore assemblage was 2.6 SD. Accordingly, unimodal methods were followed. The CCA (Fig. 3b) revealed sites and species distribution along this environmental subset. The others were also plotted as passive variables to avoid overfitting. The vectors show that salinity exhibits the longest gradient and is strongly correlated with the CCA1, indicating a strong relationship with coccolithophore distribution. Some sites from the Alboran and Balearic Seas and the taxa medium Gephyrocapsa and E. huxleyi $(>4 \mu \mathrm{m})$ were found to be distributed along the CCA2. Individual CCAs (Table 1) to calculate $\lambda_{1} / \lambda_{2}$ showed that salinity was the most important variable among those found to be significant. Variance partitioning revealed that these significant variables accounted for $38.9 \%$ of the cumulative variance in the coccolithophore training set and salinity explained a large proportion of this variance $(15.5 \%)$.

\subsection{Transfer functions}

Salinity explained the largest amount of variation in the coccolithophore assemblages and was therefore chosen to develop the coccolithophore-based transfer function. Additionally, comparison among the $R_{\text {boot }}^{2}$ from preliminary calibration models for each variable confirmed the best predictive power for salinity (Table 1).

Among the WA-PLS models for salinity, the twocomponent model (WA-PLS2) was chosen as the most suitable since it afforded a reduction of $6.4 \%$ in the RMSEP. The ideal number of analogs for the MAT was six.

The analyses of the amount of down-core variance explained by the summer, winter, and annual salinity reconstructions at nine different depths and their statistical significance revealed that the mean annual reconstruction at $10 \mathrm{~m}$ explained the highest variance. Hence, the reconstruction for core CEUTA10PC08 was based on the mean annual salinity data at $10 \mathrm{~m}$ depth and referred to as SSS reconstruction.

Five samples showed higher residuals than the SD of salinity and were preliminary identified as potential outliers (Supplement). However, only one of these samples (CO-81-2/TK2) was identified as an outlier in both the MAT and WAPLS regression methods. This had a bright yellowish color under the microscope, likely due to the effect of diagenetic processes. In order to retain the maximum number of observations representing modern environmental conditions, only this sample was removed from subsequent model implementations, leading to an improvement of the MAT and WAPLS2 $R_{\text {boot }}^{2}$ coefficient of 3.4 and $6.6 \%$, respectively, and reducing both Max_Bias boot and RMSEP (Table 2).

The final MAT and WA-PLS2 models showed similar quality predictions (Table 2). The salinity values in the modern training set vary from 36.2 to 38.2 psu. Intermediate values (37.1-37.6 psu) are less well represented by the observations (Fig. 4a). MAT- and WA-PLS2-predicted values are shown in Fig. 4b, c. The predicted vs. observed values from both models approach the diagonal of slope one (which indicates perfect predictions) reasonably well (Fig. 4d, e). The residuals for the MAT and WA-PLS2 models (Fig. 4f, g) are equally distributed around zero and show no apparent trends.

\subsection{SSS reconstruction}

SSS trends and values reconstructed for the CEUTA10PC08 core derived from both the MAT and WA-PLS2 are very similar (Fig. 5a, b). These only differ during the stadials associated with Heinrich events 2 and 1 (H2 and $\mathrm{H} 1)$, when the 

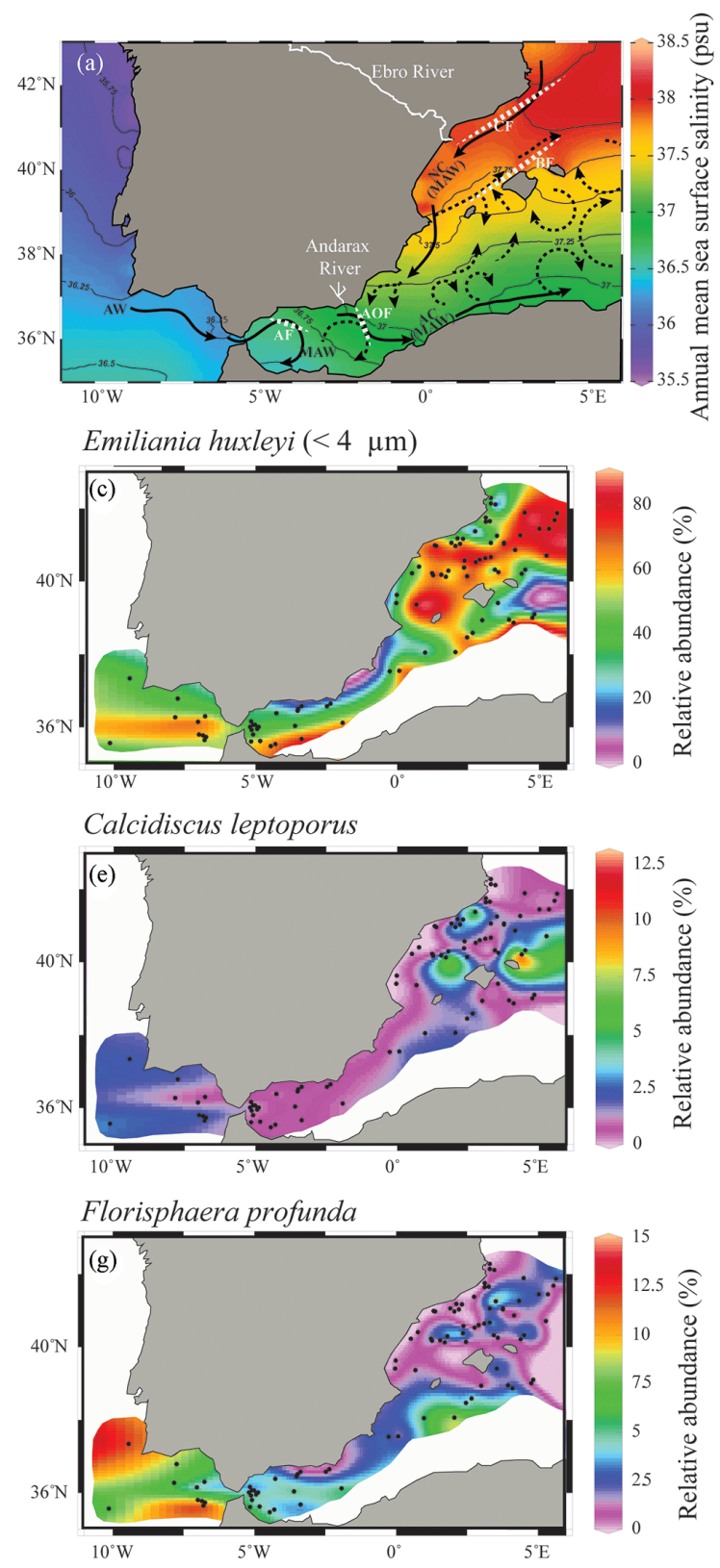
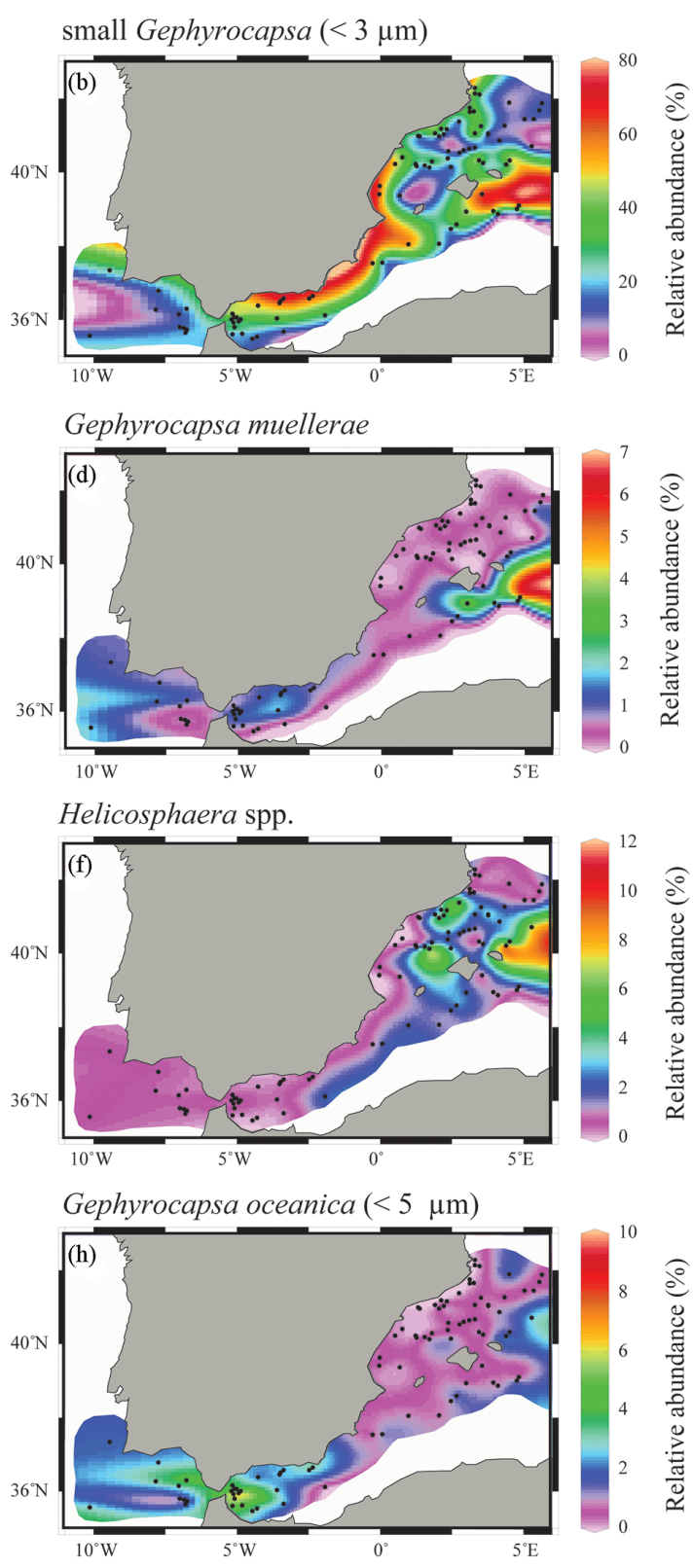

Figure 2. Geographical distribution of the main coccolithophore taxa. Panel (a): annual mean salinity at $10 \mathrm{~m}$ depth and surface circulation patterns in the study area; permanent trajectories (black arrows) and semipermanent mesoscale features (dashed arrows). Legend: AF Alboran Front; AOF - Almería-Orán Front; CF - Catalan Front; BF - Balearic Front; AW - Atlantic Water; MAW - Modified Atlantic Water; AC - Algerian Current; NC - Northern Current. Distribution, according to their relative abundance (\%), of (b) small Gephyrocapsa $(<3 \mu \mathrm{m}),(\mathbf{c})$ E. huxleyi $(<4 \mu \mathrm{m}) \mathrm{m}$, (d) G. muellerae, (e) C. leptoporus, (f) Helicosphaera spp., (g) F. profunda, (h) G. oceanica $(<5 \mu \mathrm{m})$.

WA-PLS2-estimated SSS shows more pronounced salinity decreases.

The SSS reconstructions obtained from core CEUTA10PC08 (Fig. 5a) can be divided into three intervals:

i. The period from 25.5 to $15.5 \mathrm{ka}$ is characterized by higher values that oscillate between 37.8 and 37 psu.
Lower values are found from 20 to $18 \mathrm{ka}$, followed by a drop of $0.8 \mathrm{psu}$ at $17.3 \mathrm{ka}$.

ii. The period from 15.5 to $9 \mathrm{ka}$ shows fast, largeamplitude changes. An abrupt decrease from 37.9 to 36.9 psu can be recognized at $15 \mathrm{ka}$, followed by large peaks of high values at 12.8, 11.1, and $10.2 \mathrm{ka}$. 

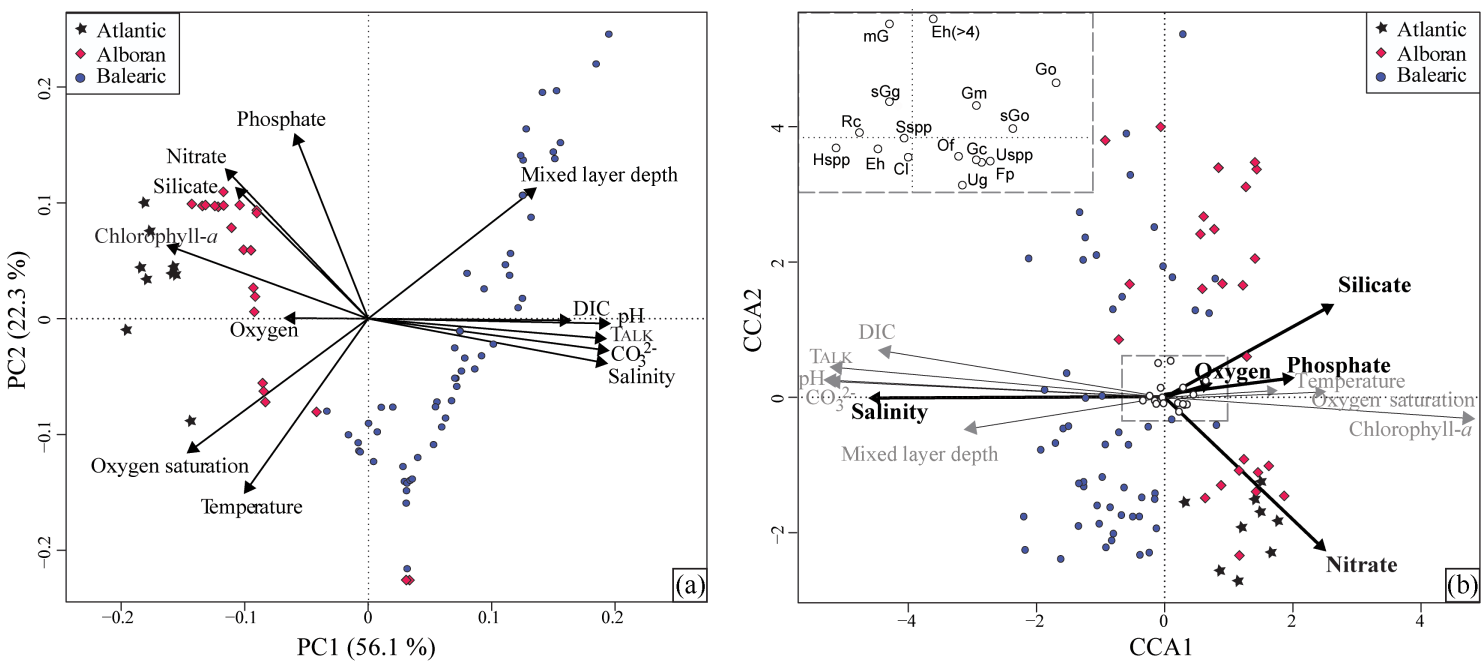

Figure 3. Multivariate analyses. Panel (a): PCA based on the 13 initial environmental variables. Panel (b): CCA ordination plot with the site scores scaled by eigenvalues. The 88 sites are represented with their location in the Atlantic Ocean, Alboran Sea or Balearic Sea. Active and passive environmental vectors are represented by black and gray arrows, respectively. Scaling for the 16 taxa scores (open circles) is shown at the top left corner. mG: medium Gephyrocapsa; Eh (>4): E. huxleyi (> $4 \mu \mathrm{m})$; Eh: E. huxleyi; sGg: small Gephyrocapsa; Gm: G. muellerae; Go: G. oceanica; sGo: small G. oceanica; Rc: R. clavigera; Sspp: Syracosphaera spp.; Of: O. fragilis; Gc: G. cf. caribbeanica; Hspp: Helicosphaera spp.; Cl: C. leptoporus; Uspp: Umbellosphaera spp.; Ug: Umbilicosphaera spp.; Fp: F. profunda.

Table 1. Multivariate analyses results. $\lambda_{1} / \lambda_{2}$ : individual CCA. Preliminary model coefficients from the MAT and WA-PLS2. $R_{\text {boot }}^{2}:$ bootstrapped coefficient of determination between the observed and predicted values. RMSEP: root-mean-square error of prediction.

\begin{tabular}{lcccccc}
\hline & & \multicolumn{2}{c}{ MAT } & \multicolumn{2}{c}{ WA-PLS } \\
\cline { 4 - 6 } Variable & $\lambda_{1} / \lambda_{2}$ & $\%$ Explained variance & Boot_R $R^{2}$ & RMSEP & Boot_R $R^{2}$ & RMSEP \\
\hline Salinity* & 1.38 & 15.47 & 0.83 & 0.30 & 0.75 & 0.33 \\
Nitrate* & 0.65 & 8.14 & 0.45 & 0.32 & 0.39 & 0.33 \\
Phosphate & 0.25 & 4.89 & 0.36 & 0.02 & 0.19 & 0.02 \\
Silicate* & 0.22 & 8.93 & 0.56 & 0.24 & 0.40 & 0.26 \\
Oxygen* & 0.1 & 1.46 & 0.15 & 0.05 & 0.05 & 0.05 \\
Chlorophyll $a$ & & 0.61 & 0.05 & 0.58 & 0.05 \\
Temperature & & 0.12 & 0.52 & 0.07 & 0.53 \\
Oxygen Saturation & & 0.20 & 1.04 & 0.18 & 1.02 \\
Mixed Layer Depth & & 0.31 & 0.19 & 0.25 & 0.19 \\
CO ${ }_{3}^{2-}$ & & 0.74 & 0.02 & 0.70 & 0.02 \\
pH & & 0.70 & 0.02 & 0.67 & 0.02 \\
$T_{\text {ALK }}$ & & 0.70 & 0.00 & 0.67 & 0.004 \\
DIC & & 0.51 & 13.31 & 0.48 & 13.16 \\
\hline
\end{tabular}

* Variables determined by ordination based on AIC.

iii. The period from 9 to 4.5 ka records the lowest values, which vary between 37 and 36.5 psu, and shows a general decreasing trend.

On average, the errors associated with both SSS reconstructions are of a similar magnitude: $\pm 0.15 \mathrm{psu}$ for the MAT and \pm 0.17 psu for WA-PLS (Fig. 5a). Squared chord distances between fossil and modern assemblages (Fig. 5b) revealed that many samples from 25.5 to 16 ka were above the 10th percentile. A comparison between $\mathrm{PC}_{\text {fossil }}$ and the SSS reconstruction is depicted in Fig. 5c, showing generally good agreement, especially for the last $16 \mathrm{kyr}$.

\section{Discussion}

\subsection{Geographic coccolithophore distribution and SSS}

E. huxleyi $(<4 \mu \mathrm{m})$ and small Gephyrocapsa are widespread in the western Mediterranean, as previously reported for surface sediment and water column samples (Álvarez et al., 

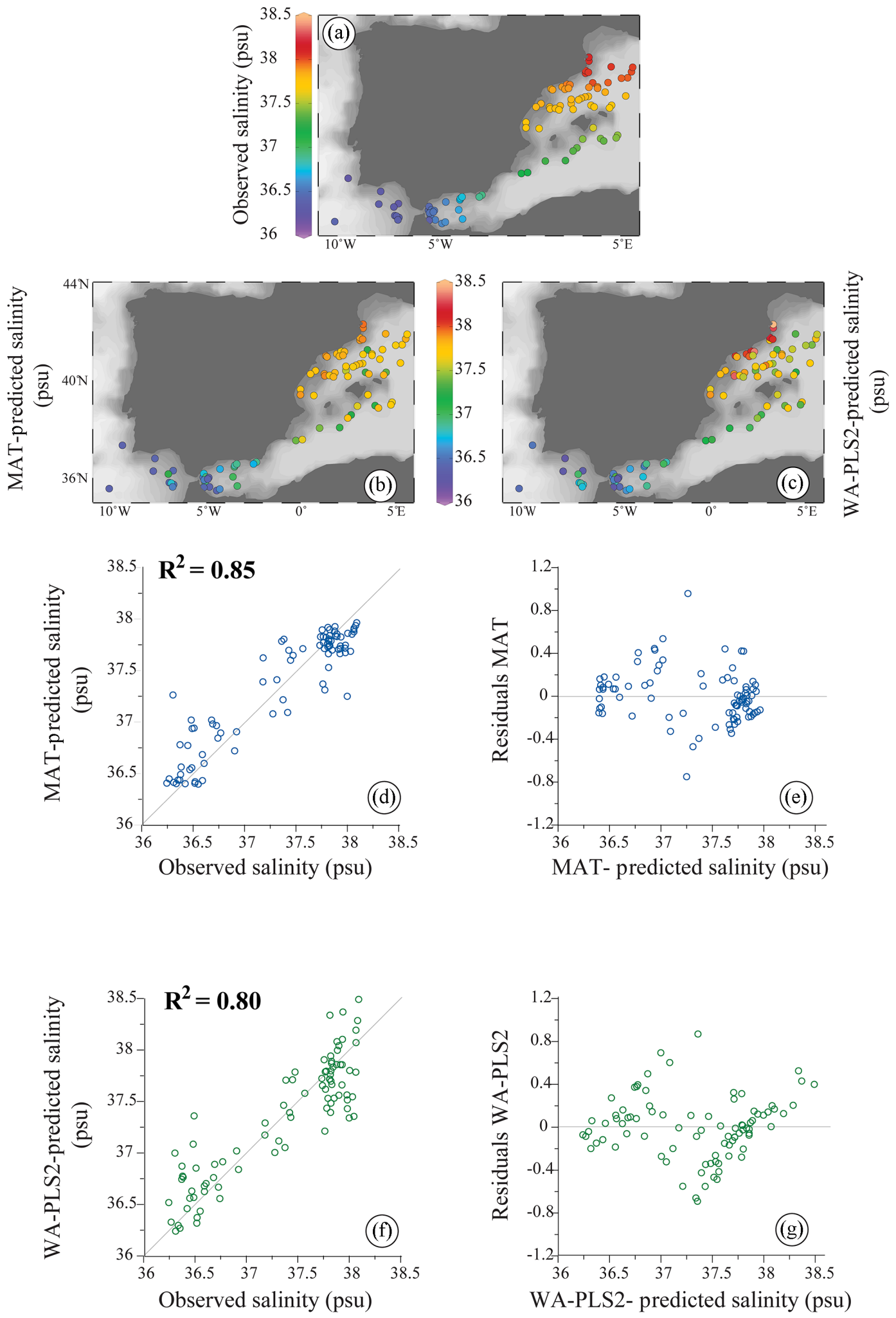

Figure 4. Diagnostic graphs of the models: (a) observed salinity values; (b) MAT-predicted salinity values; (c) WA-PLS2-predicted salinity values; (d) observed vs. MAT-predicted salinity values; (e) observed vs. WA-PLS2-predicted salinity values; (f) MAT-predicted salinity values vs. residuals; (g) WA-PLS2-predicted salinity values vs. residuals. 

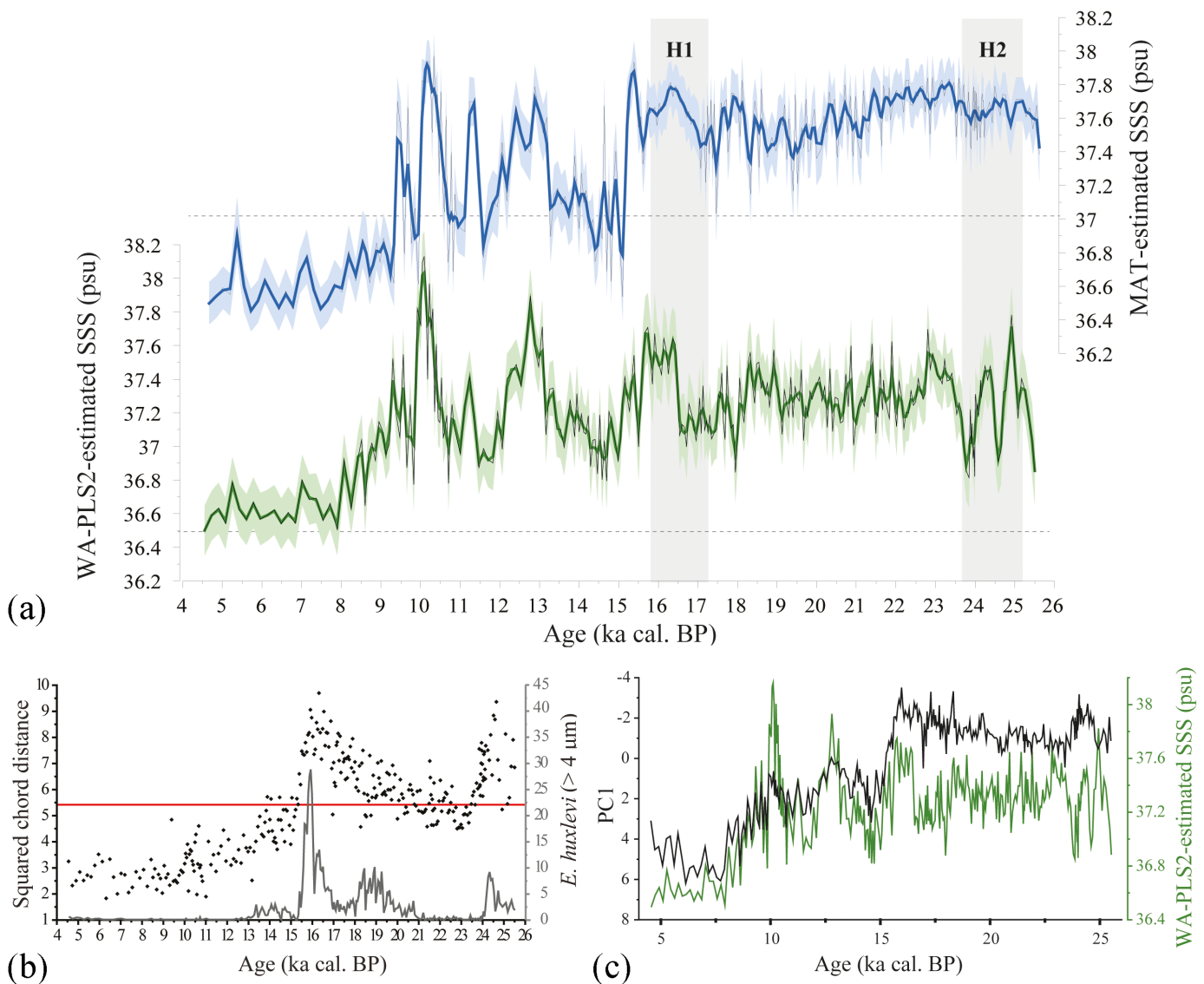

Figure 5. Panel (a): SSS reconstructions for the CEUTA10PC08 core derived from the MAT (blue) and WA-PLS2 (green). The thin black lines represent the estimated values. The thick blue and green lines represent these original data fitted to a three-point moving average smoothing spline. Pale blue or green shading represent the error range, and dashed lines indicate current annual mean SSS in the Alboran Sea from the WOA13 (Zweng et al., 2013). Panel (b): dissimilarity between modern and fossil assemblages (black dots) measured by squared chord distance (left axis) plotted vs. age. The red line indicates the 10th percentile. Relative abundance of the species E. huxleyi (> $4 \mu \mathrm{m})(\%$; right axis). Panel (c): profiles comparing the $\mathrm{PC} 1_{\text {fossil }}$ (black line) and WA-PLS2-estimated SSS (green line).

Table 2. Model coefficients from the final MAT and WA-PLS2 cross-validated by bootstrapping for SSS, after removal of one outlier. $R_{\text {boot }}^{2}$ : bootstrapped coefficient of determination between the observed and predicted values. Max_Bias boot: bootstrapped maximum bias. RMSEP: root-mean-square error of prediction (psu).

\begin{tabular}{lcc}
\hline & MAT & WA-PLS2 \\
\hline$R_{\text {boot }}^{2}$ & 0.85 & 0.80 \\
Max_Bias $_{\text {boot }}$ & 0.23 & 0.22 \\
RMSEP & 0.29 & 0.30 \\
\hline
\end{tabular}

2010; Knappertsbusch, 1993; Oviedo et al., 2015). These taxa, especially E. huxleyi $(<4 \mu \mathrm{m})$, are cosmopolitan and tolerate wide ranges of temperature and salinity (Winter et al., 1994). G. muellerae abundance is higher southeast of the Balearic Islands, where the MAW encounters more saline and warmer Mediterranean waters, and close to the Alboran Front, possibly reflecting the species' preference for nutrient- rich waters, as reported for sediment trap samples in the Alboran Sea (Bárcena et al., 2004; Hernández-Almeida et al., 2011). C. leptoporus and Helicosphaera spp. (Fig. 2e, f) show similar spatial distributions and abundances. Interestingly, the CCA suggests that Helicosphaera spp. have a preference for more saline waters (Fig. 3b). By contrast, in paleoceanographic works this species has been linked to fresher and turbid waters in the Mediterranean Sea (Ausín et al., 2015; Colmenero-Hidalgo et al., 2004; Grelaud et al., 2012). Helicosphaera spp. abundance in surface sediments from the northeastern Balearic Island has also been related to upwelling events (Álvarez et al., 2010). Similarly, the abundance of $C$. leptoporus in the Alboran Sea has been linked to nutrient-rich waters (Bárcena et al., 2004). The similar patchy pattern shown by both species may be related to the temporary upwelling of nutrient-rich waters associated with frontal structures in the area limited by the Balearic and Catalan fronts (Font et al., 1988). In agreement with this interpretation, the co-occurrence of both species in other 
Mediterranean locations has already been linked to highly productive coccolithophore periods and pre-upwelling events (Hernández-Almeida et al., 2011; Ziveri et al., 2000). The CCA (Fig. 3b) suggests that $F$. profunda and G. oceanica $(<5 \mu \mathrm{m})$ would be associated to less saline waters. This notion may partly be a consequence of their higher abundance in Atlantic waters (Fig. 2d). G. oceanica has already been proposed as a tracer for AW influx in the western Mediterranean Sea (Álvarez et al., 2010; Bárcena et al., 2004; Knappertsbusch, 1993; Oviedo et al., 2015). Similarly, the F. profunda spatial distribution reflects the path of the Algerian current (Fig. 2a, d), formed by recent and fresher MAW (Fig. 2a, d). Low percentages of $F$. profunda patchily distributed south of the Ebro River and in the Catalan-Balearic Sea suggest that this species may also be affected by the influence of river discharges (Álvarez et al., 2010). These results suggest that F. profunda and G. oceanica proliferate mainly in waters of Atlantic origin but not exclusively, as indicated by their presence in the eastern Mediterranean (Knappertsbusch, 1993; Malinverno et al., 2008) where Atlantic influence becomes diluted.

Salinity was highly correlated with $\mathrm{CO}_{3}^{2-}$ and $\mathrm{pH}$ (Fig. 3a, b). From the study of coccolithophore distributions in water column samples and in situ environmental measurements in the Mediterranean Sea, Oviedo et al. (2015) found exactly the same variables as being the most important factors when accounting for changes in heterococcolithophore assemblages. In our study, multivariate analyses revealed that salinity was significant and was the most important variable of those studied to explain the variance in coccolithophore data in this modern training set. However, the individual importance and proportion of variance explained by each of the significant variables was not assessed in the study of Oviedo et al. (2015). Despite this, the authors discarded salinity as a final explanatory variable, arguing that $E$. huxleyi, the most abundant and ubiquitous extant coccolithophore (Cros and Fortuño, 2002), inhabits a wide salinity range, suggesting a negligible ecological effect of salinity on coccolithophores. Contrary to this reasoning, the direct relationship between varying salinities and the morphology of $E$. huxleyi has been demonstrated by several authors (Bollmann and Herrle, 2007; Bollmann et al., 2009; Fielding et al., 2009; Green et al., 1998; Paasche et al., 1996; Schouten et al., 2006) in both culture experiments and marine surface sediment samples. Oviedo et al. (2015) later explained the strong and negative relationship that they found between salinity and G. oceanica, G. muellerae and E. huxleyi morphotype B/C distributions as being a consequence of their carryover by the $\mathrm{AW}$ through the Mediterranean. Instead of this, however, we interpret the AW influx as promoting the optimal conditions for these species to thrive in the Mediterranean Sea. Therefore, the coccolithophore relationship with salinity would reflect the different water masses which coccolithophore species prefer to inhabit.
It is worth mentioning that salinity influences the solubility of $\mathrm{CO}_{3}^{2-}$ via several pathways: the solubility of free carbon dioxide in water, the solubility product constants, the concentration of hydrogen ions, and the quantity of calcium in the water (Trask, 1936). Accordingly, salinity could influence coccolithophores through coccolith calcification processes. In contrast, Bollmann and Herrle (2009) have proposed that salinity influences coccolithophores through cell turgor regulation linked to osmotic processes. Although there is no clear consensus about the mechanism through which salinity influences coccolithophores, many other studies point to a strong influence of this variable on molecular compounds only produced by coccolithophores and on specific species. In the Japan Sea, salinity has been proposed to have an ecological or physiological influence on the production of alkenone and alkenoates, which are organic compounds mainly produced by the genera Emiliania and Gephyrocapsa (Fujine et al., 2006). In the Baltic Sea, alkenone unsaturation ratios have been found to be significantly correlated with salinity (Blanz et al., 2005). In the Mediterranean Sea, Knappertsbusch (1993) found that $G$. oceanica distribution was linearly correlated with salinity. Based on such evidence, we propose that the assemblage composition may be conditioned by the optimum salinity range preferred by each species. Moreover, salinity has proved to be important to other marine unicellular planktonic groups such as diatoms (Jiang et al., 2014; Li et al., 2012) and dinoflagellate cysts (Jansson et al., 2014, and references therein), reinforcing the hypothesis of salinity as an important variable for planktonic communities in semi-enclosed basins.

\subsection{Transfer function quality}

A general good fit can be deduced for both models, although the MAT was seen to perform slightly better from a higher $R_{\text {boot }}^{2}$, a lower RMSEP (Table 2), and the comparison predicted values compared with observed values (Fig. 4). Intermediate salinity values (37.1-37.6 psu) are less well represented than the more extreme values (Fig. 4d, e). Unevenness can bias the RMSEP leading to overestimation of the predictive power of the model (Telford and Birks, 2011). While an even distribution would always be desirable, unevenness is a feature inherent to most training sets from oceanic environments. In this case, it is not severe, and the observations, although unevenly distributed along the salinity gradient, do not leave gaps. The distribution of the residuals (Fig. 4f, g) indicates the adequacy of the model.

\subsection{Down-core SSS reconstruction}

The derived MAT and WA-PLS2 SSS reconstructions (Fig. 5a) are very similar. Nevertheless, WA-PLS2 shows more marked salinity decreases than the MAT during the H2 (25.2-23.7 ka) and H1 (17.4-15.9 ka). Unlike WA-PLS, the MAT does not consider the entire data set when cal- 
culating the species optima, only the most taxonomically similar analogs, and is more sensitive to local conditions (Telford and Birks, 2009). Fossil samples lack good analogs for the $\mathrm{H} 2$ and $\mathrm{H} 1$, coinciding with large peaks of $E$. huxleyi (> $4 \mu \mathrm{m})$ (Fig. 5b). H2 and $\mathrm{H} 1$ have been linked to the entry of cold and fresher water originating from the North Atlantic ice melting in the western Mediterranean Sea (Cacho et al., 1999; Melki, 2011; Sierro et al., 2005), suggesting the preference of E. huxleyi $(>4 \mu \mathrm{m})$ not only for cold waters (Colmenero-Hidalgo et al., 2002, 2004) but also fresher waters in the past. By contrast, Bollmann and Herrle (2007) reported a current positive correlation between the size of $E$. huxleyi up to $4 \mu \mathrm{m}$ and increasing salinities from the study of globally distributed core-top samples. These authors used this relationship to estimate salinity values during the Last Glacial Maximum (LGM). Interestingly, they observed several overestimations with regard to other published values in samples characterized by high relative abundances of larger specimens of E. huxleyi $(>4 \mu \mathrm{m})$. These discrepancies suggest that $E$. huxleyi $(>4 \mu \mathrm{m})$ in ancient sediments lacks an analog in modern assemblages, as indicated by the high dissimilarity between fossil samples with high percentages of this species and modern samples (Fig. 5b).

Because the MAT is strongly dependent upon on the analogs selected (Telford and Birks, 2009) and since the WA-PLS2 reconstruction for $\mathrm{H} 2$ and $\mathrm{H} 1$ is more coherent with a freshwater inflow scenario, it seems that WA-PLS2 affords more reliable values than the MAT. Consequently, WAPLS2-estimated SSS was chosen for our final interpretations.

Transfer functions assume that the ecological response of organisms to either the environmental variable of interest or to the linear combination of this important variable with others has not changed significantly over the time span represented by the fossil assemblage (Birks, 1995). The good agreement observed between $\mathrm{PC}_{\text {fossil }}$ and the reconstructed SSS patterns from $16 \mathrm{ka}$ onwards (Fig. 5c) suggests that the SSS transfer function fulfills this assumption back to $16 \mathrm{ka}$. Larger differences are observed from 25 to $16 \mathrm{ka}$, possibly promoted by the lack of analogs during this time span, discussed above. Consequently, the SSS reconstruction from 25 to $16 \mathrm{ka}$ will not be discussed further.

\subsection{SSS changes in the Alboran Sea over the last $15.5 \mathrm{kyr}$}

\subsubsection{Termination $1 \mathrm{~b}(\mathrm{~T} 1 \mathrm{~b})$}

A decrease in salinity of about $0.6 \pm 0.15$ psu occurred from 15.4 to $14.6 \mathrm{ka}$ (Fig. 6a). The global sea-level rise of $\sim 20 \mathrm{~m}$ during meltwater pulse 1a (mwp-1a) has been dated between 14.6 and $14 \mathrm{ka}$ (Stanford et al., 2006, and references therein). Since this section covers 3000 years with no control point (Fig. 6a), it could be an artifact of poorly constrained chronology for this time interval. Nevertheless, this seems unlikely because other authors (Duplessy et al., 1992;
Emeis et al., 2000; Kallel et al., 1997) have reported SSS decreases in different regions of the Mediterranean Sea and Atlantic Ocean at this time from a combination of oxygen isotope $\left(\delta^{18} \mathrm{O}\right)$ and SST data. These salinity decreases are larger than that observed for the CEUTA10PC08 core. For instance, Duplessy et al. (1992) identified a salinity drop of about 2.5 psu in an Atlantic core west of the Strait of Gibraltar. It is worth mentioning that the salinity changes estimated by this method depend strongly on the accuracy of the SST record (Schmidt, 1998) and the unknown salinity-seawater $\delta^{18} \mathrm{O}$ relationship in the past (Rohling, 1999), being sensitive to several deviations and uncertainties that are difficult to assess (Rohling, 2000; Rohling and Bigg, 1998; Schmidt, 1999). Although the uncertainty in the chronology prevents a robust correlation, the smaller SSS decrease identified in the SSS reconstruction could be related to the Laurentide ice sheet melting and retreating at $\sim 15.5 \mathrm{ka}$ (Clark et al., 2001). This event has already been proposed to be the cause of the freshwater input identified at $15.3 \mathrm{ka}$ south of Iceland via advection within the North Atlantic Current (NAC) and subsequently its northern branch (Thornalley et al., 2010). Similarly, the southeastern branch of the NAC could have advected freshwater to the study area.

\subsubsection{Bølling-Allerød (B-A)}

The SSS values are generally low for the $\mathrm{B}-\mathrm{A}$, the $\mathrm{B} \varnothing$ lling being fresher than the Allerød (Fig. 6a). Owing to the global sea-level rise during the $\mathrm{B}-\mathrm{A}$, a greater volume of AW would have entered through the Strait, decreasing the average SSS. This period of reduced salinity also coincides with the highest values of total concentration of $\mathrm{C}_{37}$ alkenones, a proxy of organic-matter preservation, from a nearby core located off the coast of Malaga (Ausín et al., 2015) (Fig. 6b). This accumulation of high amounts of organic matter resulted in the formation of the so-called organic-rich layer (ORL-1) (Cacho et al., 2002) in the western Mediterranean, although its origin is still under debate (Rogerson et al., 2008; Rohling et al., 2015). The joint effect of a salinity reduction of $0.8 \mathrm{psu}$ and a temperature increase of $3{ }^{\circ} \mathrm{C}$ (Cacho et al., 2001) (Fig. 6c) would have led to a significant reduction in sea surface density, possibly prompting stagnation of the upper water column. This, along with increased organic-matter export to the seabed (Ausín et al., 2015) and reduced deep-basin ventilation (Martínez-Ruiz et al., 2015), would have hampered organic-matter mineralization, reinforcing the formation of the ORL-1 in the Alboran Sea. According to Rohling et al. (2015), the origin of ORL-1 lies in hydraulic changes in the Strait of Gibraltar (Bernoulli aspiration depth) and/or the inhibition of deep-water formation in the Gulf of Lion, both resulting from a drastic reduction in seawater density. Those authors have shown that the mwp-1a and the monsoon flooding into the eastern Mediterranean were insufficient to trigger these mechanisms and demonstrated that the Alpine meltwater input into the NW Mediterranean at this time (Ivy-Ochs 


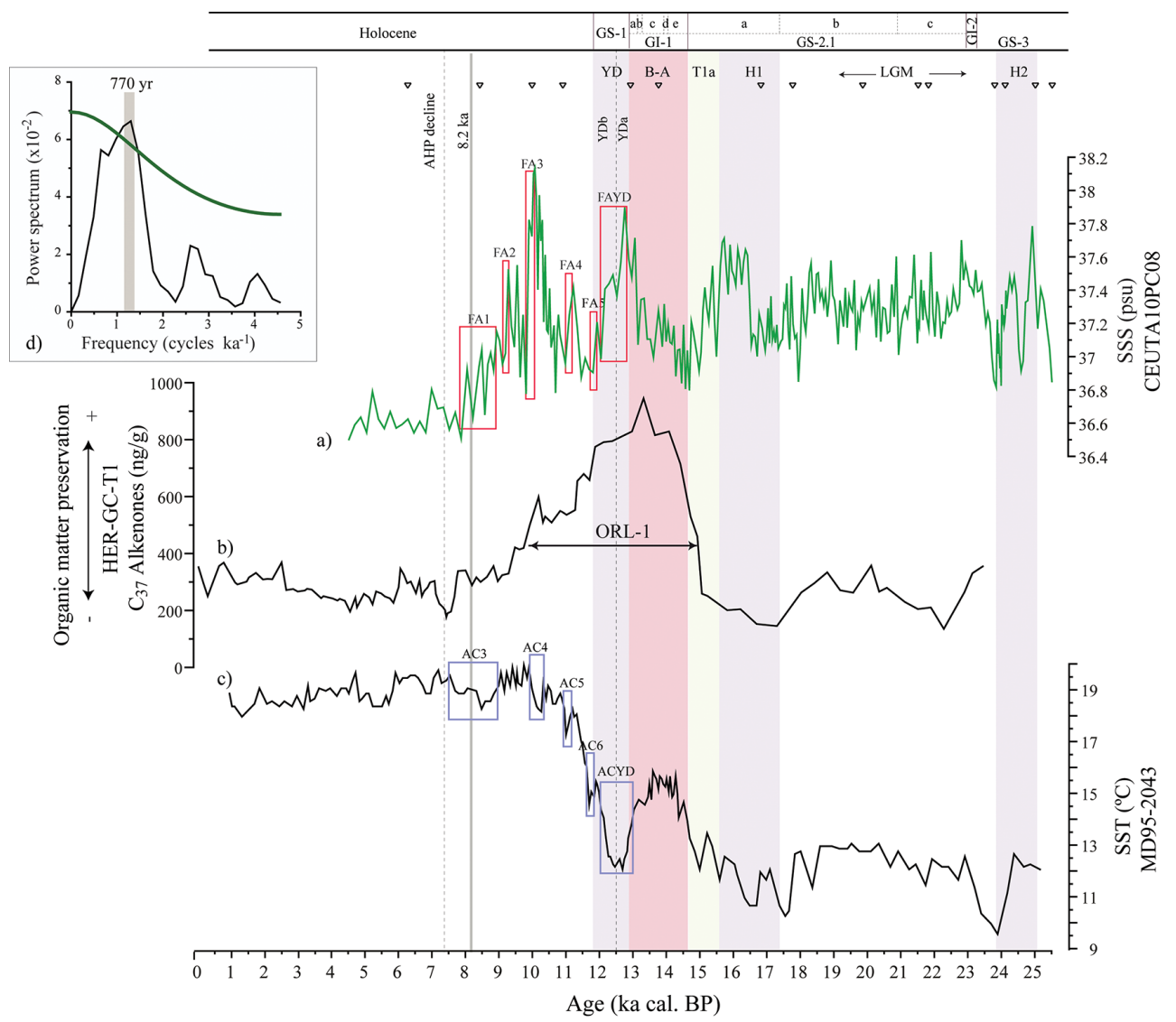

Figure 6. Paleoenvironmental records in the Alboran Sea: (a) WA-PLS2-SSS reconstruction for CEUTA10PC08 core; age control points marked by triangles. Panel (b): $\mathrm{C}_{37}$ Alkenones from core HER-GC-T1 (Ausín et al., 2015). Panel (c): alkenone-SST from core MD95-2043 (Cacho et al., 2001). Red boxes represent the Alboran cooling events (AC_events). Panel (d): REDFIT periodogram of the SSS reconstruction for the Holocene. The gray bar marks the only significant peak at the $95 \%$ significance level (green line).

et al., 2007) may have played an essential role as freshwater forcing.

\subsubsection{Younger Dryas (YD) and the Holocene}

The YD exhibits a shift from higher to lower SSS values, decreasing by a total of $0.6 \mathrm{psu}$ along its two phases: YDa and $\mathrm{YDb}$ (Fig. 6a). Several large short-term SSS fluctuations occurred from the onset of the YD throughout the early Holocene (up to $8 \mathrm{ka}$ ). This time span coincides with a sea-level rise of $\sim 30 \mathrm{~m}$ (Peltier and Fairbanks, 2006) due to short-lived freshwater inputs associated with residual melting of the Northern Hemisphere ice sheets (Andrews and Dunhill, 2004; Elmore et al., 2015; Seidenkrantz et al., 2013; Tornqvist and Hijma, 2012). Six brief periods of an SSS decreasing trend were identified at 12.77-12.06, 11.95-11.71, 11.24-11.00, 10.09-9.83, 9.30-9.12, and 8.95$7.90 \mathrm{ka}$ (Fig. 6a). REDFIT spectral analysis reveals a periodicity of $770 \pm 40$ years (Fig. 6d), very similar to the $730 \pm 40$ years cycle found by Cacho et al. (2001) in an SST record in the Alboran Sea, which was punctuated by the so-called Alboran cooling events (AC_events) (Fig. 6c). Although this similarity does not necessarily imply a causal relationship, the timing of SSS decreases is comparable to that of the AC_events (Table 3), suggesting a common origin. Cacho et al. (2001) have associated the AC_events with influxes of cold Atlantic waters in the Alboran Sea during icerafted debris discharges (so-called Bond events) (Bond et al., 1997) (Table 3). These latter authors noted that the oxygen isotopic record showed no evidence of any of the coolings found for each Bond event during the Holocene and argued that the cooler surface waters may also have been fresher, offsetting the expected temperature-driven $\delta^{18} \mathrm{O}$ enrichment in their records. Similarly, the highly resolved $\delta^{18} \mathrm{O}$ profile reported by Cacho et al. (2001) does not show any of the expected oxygen isotopic enrichments associated with the AC_events, supporting the presence of fresher waters at those times. We suggest that freshwater advection (FA) events (as well as AC_events) would have resulted from the influx of fresher and colder Atlantic waters in the Alboran Sea related to the southeastward drifting of meltwater from the Labrador, Greenland and Iceland seas (Bond et al., 1997). 
Table 3. Timing (given in ka cal. BP) of freshwater advection events (FA) deduced from SSS decreases in the CEUTA10PC08 core (this study) and their magnitude, Alboran cooling events (AC_events) from core MD 95-2043 (ACYD-AC3; Cacho et al., 2001), and Bond events in the North Atlantic (Bond et al., 1997). ACYD: Alboran cooling during Younger Dryas; FAYD: freshwater advection during Younger Dryas.

\begin{tabular}{lrrr}
\hline SSS decreases & SSS change (psu) & AC_events & Bond events \\
\hline FAYD & $0.79 \pm 0.15$ & ACYD & \\
$12.77-12.06$ & & $13.1-12.0$ & 12.5 \\
FA5 & $0.22 \pm 0.16$ & AC6 & - \\
$11.95-11.71$ & & $11.9-11.65$ & \\
FA4 & $0.41 \pm 0.16$ & AC5 & \\
$11.24-11.00$ & & $11.21-10.95$ & 11.1 \\
FA3 & $1.0 \pm 0.15$ & AC4 & \\
$10.09-9.83$ & & $10.34-9.95$ & 10.3 \\
FA2 & $0.42 \pm 0.15$ & - & \\
$9.3-9.12$ & & AC3 & 9.4 \\
FA1 & $0.57 \pm 0.15$ & $9.08-7.56$ & 8.1 \\
$8.95-7.9$ & & & \\
\hline
\end{tabular}

FA events only occurred during the early Holocene, while AC_events and Bond events have also been identified through the middle and late Holocene. Wanner et al. (2014) concluded that, unlike the events occurring later, early Holocene Bond events originated from changes in the meridional overturning circulation due to meltwater pulses from the Northern Hemisphere ice sheets. It is likely that FA events would only have been noticeable when this mechanism was operating (i.e. the early Holocene), since very little meltwater was present after that period (Elmore et al., 2015).

An SSS increase of $0.87 \pm 0.15 \mathrm{psu}$ is observed from 10.7 to $10 \mathrm{ka}$. Because the western Mediterranean is a semienclosed basin, local conditions may have played a role as additional feedbacks for this rapid high-amplitude variability. For this brief period, Frigola et al. (2008) have demonstrated the most pronounced weakening of the Mediterranean thermohaline circulation for the last $50 \mathrm{ka}$. The consequent reduction in Atlantic-Mediterranean water exchange, along with the maximum summer insolation and inland aridity (Fletcher et al., 2010), would have led to more saline surface waters.

FA1 includes the $8.2 \mathrm{ka}$ event (Alley et al., 1997), which has been linked to a sub-thermocline freshening of $0.5 \mathrm{psu}$ in the North Atlantic (Thornalley et al., 2009). However, no distinctive SSS changes are observed in relation to this event, suggesting that it would have had a negligible effect on surface salinity in the Alboran Sea. Minimum SSS values are recorded at $7.8 \mathrm{ka}$, possibly related to maximum high-stand conditions reached at $7.4 \mathrm{ka}$ (Zazo et al., 2008), along with the influence of the African Humid Period (AHP; 11-5.5 ka) over the study area, especially up to its decline at $7.4 \mathrm{ka}$ (deMenocal et al., 2000). From 7.8 to $4.5 \mathrm{ka}$, salinity values level off around 36.6 psu, close to present SSS values.

\section{Conclusions}

Multivariate statistical analyses show that the distribution of modern coccolithophore assemblages in the Atlantic Ocean, west of the Strait of Gibraltar, and the western Mediterranean was mainly influenced by annual mean salinity at $10 \mathrm{~m}$ depth. MAT and WA-PLS2 calibration models show similar outcomes. These models were applied to coccolithophore assemblages from a fossil core to reconstruct SSS at a high resolution for the last $25 \mathrm{kyr}$ in the Alboran Sea. Statistical analyses reveal assemblages lacking good modern analogs in relation to the species E. huxleyi $>4 \mu \mathrm{m}$ during $\mathrm{H} 2$ and $\mathrm{H} 1$ and part of the LGM, preventing further interpretations for these periods. A low SSS was found for the B-A, possibly due to the post-glacial sea-level rise. The consequent reduction in sea surface density is suggested to have reinforced the formation of the ORL-1. During the YD and Holocene, six brief, abrupt SSS decreases at 12.77-12.06, 11.95-11.71, $11.24-11.00,10.09-9.83,9.30-9.12$, and 8.95-7.90 ka were linked to the advection of fresher and colder AW related to the southeastward drifting of meltwater in the North Atlantic. No evidence of the $8.2 \mathrm{ka}$ event is found in the reconstructed SSS, which reached its lowest values at $7.8 \mathrm{ka}$, coinciding with high-stand conditions in the Alboran Sea and the onset of the decline of the African Humid Period. SSS remained low from 7.8 to $4.5 \mathrm{ka}$, close to its present values.

A broader understanding of the ecological link between coccolithophore species and environmental parameters would be desirable in order to be able to place coccolithophore-based transfer functions within an ecological context in future works. Nevertheless, the diverse statistical tests performed in this study and the strong emphasis placed on assessing the validity and reliability of both the model and the reconstruction do reveal the potential of coccolithophores for developing transfer functions. The derived transfer function provides a potential independent proxy for quantitative reconstructions of SSS changes in other locations of the western Mediterranean Sea over the last $15.5 \mathrm{kyr}$.

\section{The Supplement related to this article is available online at doi:10.5194/cp-11-1635-2015-supplement.}

Acknowledgements. We thank two anonymous reviewers for their critical discussion to improve this manuscript. B. Ausín is sincerely grateful to the Core Repository of the Institute of Marine Sciences (CSIC) at Barcelona and the University of Vigo for the core-top sample supply. This study was supported by the FPU grant AP2010-2559 of the Spanish Ministry of Education to B. Ausín and by the Consolider Ingenio "GRACCIE" program CSD 2007-00067, the program SA263U14 of Junta de Castilla y León, and the programs: CGL2011-26493, VACLIODP339, CTM2008-06399-C04/MAR, CTM 2012-39599-C03-02/03 and MOWER (CTM 2012-39599-CO3-02/03) of the Spanish Ministry 
of Economy and Competitiveness.

Edited by: L. Beaufort

\section{References}

Álvarez, M. C., Amore, F. O., Cros, L., Alonso, B., and AlcántaraCarrió, J.: Coccolithophore biogeography in the Mediterranean Iberian margin, Revista Española de Micropaleontología, 42, 359-372, 2010.

Alley, R. B., Mayewski, P. A., Sowers, T., Stuiver, M., Taylor, K. C., and Clark, P. U.: Holocene climatic instability: A prominent, widespread event 8200 yr ago, Geology, 25, 483-486, 1997.

Andrews, J. T. and Dunhill, G.: Early to mid-Holocene Atlantic water influx and deglacial meltwater events, Beaufort Sea slope, Arctic Ocean, Quaternary Res., 61, 14-21, 2004.

Ausín, B., Flores, J. A., Bácena, M. A., Sierro, F. J., Francés, G., Gutiérrez-Arnillas, E., Hernández-Almeida, I., Martrat, B., Grimalt, J. O., and Cacho, I.: Coccolithophore productivity and surface water dynamics in the Alboran Sea during the last $25 \mathrm{kyr}$, Palaeogeogr. Palaeocl., 418, 126-140, 2015.

Bárcena, M. A., Flores, J. A., Sierro, F. J., Pérez-Folgado, M., Fabres, J., Calafat, A., and Canals, M.: Planktonic response to main oceanographic changes in the Alboran Sea (Western Mediterranean) as documented in sediment traps and surface sediments, Mar. Micropaleontol., 53, 423-445, 2004.

Baumann, K. H., Andruleit, H., Boeckel, B., Geisen, M., and Kinkel, H.: The significance of extant coccolithophores as indicators of ocean water masses, surface water temperature, and palaeoproductivity: a review, Palaeont. Z., 79, 93-112, 2005.

Beaufort, L., Lancelot, Y., Camberlin, P., Cayre, O., Vincent, E., Bassinot, F., and Labeyrie, L.: Insolation Cycles as a Major Control of Equatorial Indian Ocean Primary Production, Science, 278, 1451-1454, 1997.

Beaufort, L., de Garidel-Thoron, T., Mix, A. C., and Pisias, N. G.: ENSO-like Forcing on Oceanic Primary Production During the Late Pleistocene, Science, 293, 2440-2444, 2001.

Bèthoux, J. P.: Budgets of the Mediterranean Sea. Their dependance on the local climate and on the characteristics of the Atlantic waters, Oceanol. Acta, 2, 157-163, 1979.

Birks, H. J. B.: Quantitative palaeoenvironmental reconstructions, in: Statistical Modelling of Quaternary Science Data, technical guide 5, edited by: Maddy, D., and Brew, J. S., Quaternary Research Association, Cambridge, 271 pp., 1995.

Birks, H. J. B., Line, J. M., Juggins, S., Stevenson, A. C., and Braak, C. J. F. T.: Diatoms and pH Reconstruction, Philos. T. Roy. Soc. B, 327, 263-278, 1990.

Blanz, T., Emeis, K.-C., and Siegel, H.: Controls on alkenone unsaturation ratios along the salinity gradient between the open ocean and the Baltic Sea, Geochim. Cosmochim. Ac., 69, 3589-3600, 2005.

Bollmann, J. and Herrle, J. O.: Morphological variation of Emiliania huxleyi and sea surface salinity, Earth Planet. Sc. Lett., 255, 273-288, 2007.

Bollmann, J., Herrle, J. O., Cortés, M. Y., and Fielding, S. R.: The effect of sea water salinity on the morphology of Emiliania huxleyi in plankton and sediment samples, Earth Planet. Sc. Lett., 284, 320-328, 2009.
Bond, G., Showers, W., Cheseby, M., Lotti, R., Almasi, P., deMenocal, P., Priore, P., Cullen, H., Hajdas, I., and Bonani, G.: A Pervasive Millennial-Scale Cycle in North Atlantic Holocene and Glacial Climates, Science, 278, 1257-1266, 1997.

Boyer, T. P., Antonov, J. I., Baranova, O. K., Coleman, C., Garcia, H. E., Grodsky, A., Johnson, D. R., Locarnini, R. A., Mishonov, A. V., O'Brien, T. D., Paver, C. R., Reagan, J. R., Seidov, D., Smolyar, I. V., and Zweng, M. M.: World Ocean Database 2013, NOAA Atlas NESDIS 72, Silver Spring, MD, edited by: Levitus, S. and Mishonov, A., 209 pp., 2013.

Cacho, I., Grimalt, J. O., Pelejero, C., Canals, M., Sierro, F. J., Flores, J. A., and Shackleton, N.: Dansgaard-Oeschger and Heinrich Event Imprints in Alboran Sea Paleotemperatures, Paleoceanography, 14, 698-705, 1999.

Cacho, I., Grimalt, J. O., Canals, M., Sbaffi, L., Shackleton, N. J., Schönfeld, J., and Zahn, R.: Variability of the western Mediterranean Sea surface temperature during the last 25,000 years and its connection with the Northern Hemisphere climatic changes, Paleoceanography, 16, 40-52, 2001.

Cacho, I., Grimalt, J. O., and Canals, M.: Response of the Western Mediterranean Sea to rapid climatic variability during the last 50,000 years: a molecular biomarker approach, J. Marine Syst., 33-34, 253-272, 2002.

Clark, P. U., Marshall, S. J., Clarke, G. K. C., Hostetler, S. W., Licciardi, J. M., and Teller, J. T.: Freshwater forcing of abrupt climate change during the last glaciation, Science, 293, 283-287, 2001.

Colmenero-Hidalgo, E., Flores, J.-A., and Sierro, F. J.: Biometry of Emiliania huxleyi and its biostratigraphic significance in the Eastern North Atlantic Ocean and Western Mediterranean Sea in the last 20,000 years, Mar. Micropaleontol., 46, 247-263, 2002.

Colmenero-Hidalgo, E., Flores, J. A., Sierro, F. J., Bárcena, M. A., Löwemark, L., Schönfeld, J., and Grimalt, J. O.: Ocean surface water response to short-term climate changes revealed by coccolithophores from the Gulf of Cadiz (NE Atlantic) and Alboran Sea (W Mediterranean), Palaeogeogr. Palaeocl., 205, 317-336, 2004.

Cros, L. and Fortuño, J.-M.: Atlas of northwestern Mediterranean coccolithophores, Sci. Mar., 66, 7-182, 2002.

deMenocalk, P., Ortiz, J., Guilderson, T., Adkins, J., Sarnthein, M., Baker, L., and Yarusinsky, M.: Abrupt onset and termination of the African Humid Period: rapid climate responses to gradual insolation forcing, Quaternary Sci. Rev., 19, 347-361, 2000.

Duplessy, J. C., Labeyrie, L., Arnold, M., Paterne, M., Duprat, J., and van Weering, T. C. E.: Changes in surface salinity of the North Atlantic Ocean during the last deglaciation, Nature, 358, 485-488, 1992.

Edwards, R. J., van de Plassche, O., Gehrels, W. R., and Wright, A. J.: Assessing sea-level data from Connecticut, USA, using a foraminiferal transfer function for tide level, Mar. Micropaleontol., 51, 239-255, 2004.

Elmore, A. C., Wright, J. D., and Southon, J.: Continued meltwater influence on North Atlantic Deep Water instabilities during the early Holocene, Mar. Geol., 360, 17-24, 2015.

Emeis, K.-C., Struck, U., Schulz, H.-M., Rosenberg, R., Bernasconi, S., Erlenkeuser, H., Sakamoto, T., and MartinezRuiz, F.: Temperature and salinity variations of Mediterranean Sea surface waters over the last 16,000 years from records of 
planktonic stable oxygen isotopes and alkenone unsaturation ratios, Palaeogeogr. Palaeocl., 158, 259-280, 2000.

Fatela, F. and Taborda, R.: Confidence limits of species proportions in microfossil assemblages, Mar. Micropaleontol., 45, 169-174, 2002.

Fielding, S. R., Herrle, J. O., Bollmann, J., Worden, R. H., and Montagnesd, D. J. S.: Assessing the applicability of Emiliania huxleyi coccolith morphology as a sea-surface salinity proxy, Limnol. Oceanogr., 54, 1475-1480, 2009.

Fletcher, W. J., Sanchez Goñi, M. F., Peyron, O., and Dormoy, I.: Abrupt climate changes of the last deglaciation detected in a Western Mediterranean forest record, Clim. Past, 6, 245-264, doi:10.5194/cp-6-245-2010, 2010.

Flores, J. A. and Sierro, F. J.: Revised technique for calculation of calcareous nannofossil accumulation rates, Micropaleontology, 43, 321-324, 1997.

Flores, J. A., Sierro, F. J., Francés, G., Vázquez, A., and Zamarreño, I.: The last 100,000 years in the western Mediterranean: sea surface water and frontal dynamics as revealed by coccolithophores, Mar. Micropaleontol., 29, 351-366, 1997.

Font, J., Salat, J., and Tintoré, J..: Permanent features of the circulation in the Catalan Sea (Northwestern Mediterranean), Oceanol. Acta, 9, 51-57, 1988.

Frigola, J., Moreno, A., Cacho, I., Canals, M., Sierro, F. J., Flores, J. A., and Grimalt, J. O.: Evidence of abrupt changes in Western Mediterranean Deep Water circulation during the last $50 \mathrm{kyr}$ : A high-resolution marine record from the Balearic Sea, Quatern. Int., 181, 88-104, 2008.

Fujine, K., Yamamoto, M., Tada, R., and Kido, Y.: A salinity-related occurrence of a novel alkenone and alkenoate in Late Pleistocene sediments from the Japan Sea, Organic Geochem., 37, 10741084, 2006.

García, H. E., Locarnini, R. A., Boyer, T. P., Antonov, J. I., Baranova, O. K., Zweng, M. M., Reagan, J. R., and Johnson, D. R.: World Ocean Atlas 2013, Volume 3: Dissolved Oxygen, Apparent Oxygen Utilization, and Oxygen Saturation, in: NOAA Atlas NESDIS 75, edited by: Levitus, S. and Mishonov, A., 27 pp., 2014a.

García, H. E., Locarnini, R. A., Boyer, T. P., Antonov, J. I., Baranova, O. K., Zweng, M. M., Reagan, J. R., and Johnson, D. R.: World Ocean Atlas 2013, Volume 4: Dissolved Inorganic Nutrients (phosphate, nitrate, silicate), in: NOAA Atlas NESDIS 76, edited by: Levitus, S. and Mishonov, A., 25 pp., 2014 b.

Giraudeau, J. and Rogers, J.: Phytoplankton biomass and seasurface temperature estimates from sea-bed distribution of nannofossils and planktonic foraminifera in the Benguela upwelling system, Micropaleontology, 40, 275-285, 1994.

Goyet, C., Healy, R. J., and Ryan, P. D.: Global distribution of total inorganic carbon and total alkalinity below the deepest winter mixed layer depths, ORNL/CDIAC-127, NDP-076, Carbon Dioxide Information Analysis Center, Oak Ridge National Laboratory, US Department of Energy, Oak Ridge, Tennessee, 2000.

Green, J. C., Heimdal, B. R., Paasche, E., and Moate, R.: Changes in calcification and the dimensions of coccoliths of Emiliania huxleyi (Haptophyta) grown at reduced salinities, Phycologia, 37, 121-131, 1998.

Grelaud, M., Marino, G., Ziveri, P., and Rohling, E. J. C. P. A.: Abrupt shoaling of the nutricline in response to massive freshwater flooding at the onset of the last interglacial sapropel event,
Paleoceanography, 27, PA3208, doi:3210.1029/2012PA002288, 2012.

Guerreiro, C., Oliveira, A., de Stigter, H., Cachão, M., Borges, C., Cros, L., Santos, A., Fortuño, J.-M., and Rodrigues, A.: Late winter coccolithophore bloom off central Portugal in response to river discharge and upwelling, Cont. Shelf Res., 59, 65-83, 2013.

Guerreiro, C., de Stigter, H., Oliveira, A., Cachão, M., Cros, L., Borges, C., Quaresma, L., Santos, A. I., Fortuño, J.-M., and Rodrigues, A.: Influence of the Nazaré Canyon, central Portuguese margin, on late winter coccolithophore assemblages, Deep-Sea Res. Pt. II, 104, 335-358, 2014.

Hernández-Almeida, I., Bárcena, M. A., Flores, J. A., Sierro, F. J., Sanchez-Vidal, A., and Calafat, A.: Microplankton response to environmental conditions in the Alboran Sea (Western Mediterranean): One year sediment trap record, Mar. Micropaleontol., 78, 14-24, 2011.

Incarbona, A., Di Stefano, E., Patti, B., Pelosi, N., Bonomo, S., Mazzola, S., Sprovieri, R., Tranchida, G., Zgozi, S., and Bonanno, A.: Holocene millennial-scale productivity variations in the Sicily Channel (Mediterranean Sea), Paleoceanography, 23 , PA3204, doi:10.1029/2007PA001581, 2008.

Ivy-Ochs, S., Kerschner, H., and Schlüchter, C.: Cosmogenic nuclides and the dating of Lateglacial and Early Holocene glacier variations: The Alpine perspective, Quatern. Int., 164-165, 5363, 2007.

Jansson, I.-M., Mertens, K. N., Head, M. J., de Vernal, A., Londeix, L., Marret, F., Matthiessen, J., and Sangiorgi, F.: Statistically assessing the correlation between salinity and morphology in cysts produced by the dinoflagellate Protoceratium reticulatum from surface sediments of the North Atlantic Ocean, MediterraneanMarmara-Black Sea region, and Baltic-Kattegat-Skagerrak estuarine system, Palaeogeogr. Palaeocl., 399, 202-213, 2014.

Jiang, H., Knudsen, M. F., Seidenkrantz, M.-S., Zhao, M., Sha, L., and Ran, L.: Diatom-based reconstruction of summer sea-surface salinity in the South China Sea over the last 15,000 years, Boreas, 43, 208-219, 2014.

Juggins, S.: C2 Version 1.5 Software for ecological and palaeoecological data analysis and visualisation, Newcastle University, Newcastle upon Tyne, UK, available at: http://www.staff.ncl ac.uk/stephen.juggins/software/C2Home.htm (last access: 7 July 2015), 2007.

Juggins, S.: Quantitative reconstructions in palaeolimnology: new paradigm or sick science?, Quaternary Sci. Rev., 64, 20-32, 2013.

Kallel, N., Paterne, M., Labeyrie, L., Duplessy, J.-C., and Arnold, M.: Temperature and salinity records of the Tyrrhenian Sea during the last 18,000 years, Palaeogeogr. Palaeocl., 135, 97-108, 1997.

Knappertsbusch, M.: Geographic distribution of living and Holocene coccolithophores in the Mediterranean Sea, Mar. Micropaleontol., 21, 219-247, 1993.

Li, D., Knudsen, M. F., Jiang, H., Olsen, J., Zhao, M., Li, T., Knudsen, K. L., Seidenkrantz, M.-S., and Sha, L.: A diatom-based reconstruction of summer sea-surface salinity in the Southern Okinawa Trough, East China Sea, over the last millennium, J. Quaternary Sci., 27, 771-779, 2012.

Locarnini, R., Mishonov, A., Antonov, J., Boyer, T., Garcia, H., Baranova, O., Zweng, M., Paver, C. R., Reagan, J. R., Johnson, 
D. R., Hamilton, M., and Seidov, D.: World Ocean Atlas 2013, Volume 1: Temperature, in: NOAA Atlas NESDIS 73, edited by: Levitus, S. and Mishonov, A., 40 pp., 2013.

Malinverno, E., Dimiza, M., Triantaphyllou, M., Dermitzakis, M., and Corselli, C.: Coccolithophores of the Eastern Mediterranean sea: A look into the marine microworld, Athens-GR: ION, 188, 2008.

Martínez-Ruiz, F., Kastner, M., Gallego-Torres, D., RodrigoGámiz, M., Nieto-Moreno, V., and Ortega-Huertas, M.: Paleoclimate and paleoceanography over the past 20,000 $\mathrm{yr}$ in the Mediterranean Sea Basins as indicated by sediment elemental proxies, Quaternary Sci. Rev., 107, 25-46, 2015.

MEDOCGROUP: Observation of formation of deep water in the Mediterranean Sea, 1969, Nature, 227, 1037-1040, 1970.

Melki, T.: Variation of deepwater convection in the western Mediterranean Sea (Gulf of Lion) during the last $28 \mathrm{ka}$, Quatern. Int., 241, 160-168, 2011.

Millot, C.: Circulation in the Western Mediterranean Sea, J. Marine Syst., 20, 423-442, 1999.

Monterey, G. and Levitus, S.: Seasonal Variability of Mixed Layer Depth for the World Ocean. NOAA Atlas NESDIS 14, US Gov. Printing Office, Washington, D.C., 96 pp., 1997.

Oksanen, J., Blanchet, F. G., Kindt, R., Legendre, P., Minchin, P. R., O’Hara, B., Simpson, G. L., Solymos, P., Stevens, M. H. H., and Wagner, H.: Vegan: Community Ecology Package, R package version 2.3-0, 2015.

Overpeck, J. T., Webb, T., and Prentice IC: Quantitative interpretation of fossil pollen spectra: Dissimilarity coefficients and the method of modern analogs, Quaternary Res., 23, 87-108, 1985.

Oviedo, A., Ziveri, P., Álvarez, M., and Tanhua, T.: Is coccolithophore distribution in the Mediterranean Sea related to seawater carbonate chemistry?, Ocean Sci., 11, 13-32, doi:10.5194/os11-13-2015, 2015.

Paasche, E., Brubak, S., Skattebøl, S., Young, J. R., and Green, J. C.: Growth and calcification in the coccolithophorid Emiliania huxleyi (Haptophyceae) at low salinities, Phycologia, 35, 394403, 1996.

Peltier, W. R. and Fairbanks, R. G.: Global glacial ice volume and Last Glacial Maximum duration from an extended Barbados sea level record, Quaternary Sci. Rev., 25, 3322-3337, 2006.

Prell, W. L.: The stability of low-latitude sea-surface temperatures: An evaluation of the CLIMAP reconstruction with emphasis on the positive SST anomalies, Department of Energy, Washington, D.C, 1985.

R Core Team: R: A language and environment for statistical computing, Viena, Austria, available at: http://www.R-project.org (last access: 28 July 2015), R Foundation for Statistical Computing, 2015.

Rogerson, M., Cacho, I., Jimenez-Espejo, F., Reguera, M. I., Sierro, F. J., Martinez-Ruiz, F., Frigola, J., and Canals, M.: A dynamic explanation for the origin of the western Mediterranean organic-rich layers, Geochem. Geophy. Geosy., 9, Q07U01, doi:10.1029/2007GC001936, 2008.

Rohling, E. J.: Environmental control on Mediterranean salinity and $\delta^{18} \mathrm{O}$, Paleoceanography, 14, 706-715, 1999.

Rohling, E. J.: Paleosalinity: confidence limits and future applications, Mar. Geol., 163, 1-11, 2000.

Rohling, E. J. and Bigg, G. R.: Paleosalinity and $\delta^{18} \mathrm{O}$ : A critical assessment, J. Geophys. Res.-Oceans, 103, 1307-1318, 1998.
Rohling, E. J., Marino, G., and Grant, K. M.: Mediterranean climate and oceanography, and the periodic development of anoxic events (sapropels), Earth-Sci. Rev., 143, 62-97, 2015.

Saavedra-Pellitero, M., Flores, J. A., Lamy, F., Sierro, F. J., and Cortina, A: Coccolithophore estimates of paleotemperature and paleoproductivity changes in the southeast $\mathrm{Pa}$ cific over the past $27 \mathrm{kyr}$, Paleoceanography, 26, PA1201, doi:10.1029/2009PA001824, 2011.

Saavedra-Pellitero, M., Baumann, K. H., Hernández-Almeida, I., Flores, J. A., and Sierro, F. J.: Modern sea surface productivity and temperature estimations off Chile as detected by coccolith accumulation rates, Palaeogeogr. Palaeocl., 392, 534-545, 2013.

Schlitzer, R.: Ocean Data View, http://odv.awi.de (last access: 22 July 2015), 2014.

Schmidt, G. A.: Oxygen-18 variations in a global ocean model, Geophys. Res. Lett., 25, 1201-1204, 1998.

Schmidt, G. A.: Error analysis of paleosalinity calculations, Paleoceanography, 14, 422-429, 1999.

Schouten, S., Ossebaar, J., Schreiber, K., Kienhuis, M. V. M., Langer, G., Benthien, A., and Bijma, J.: The effect of temperature, salinity and growth rate on the stable hydrogen isotopic composition of long chain alkenones produced by Emiliania huxleyi and Gephyrocapsa oceanica, Biogeosciences, 3, 113-119, doi:10.5194/bg-3-113-2006, 2006.

Seidenkrantz, M.-S., Ebbesen, H., Aagaard-Sørensen, S., Moros, M., Lloyd, J. M., Olsen, J., Knudsen, M. F., and Kuijpers, A.: Early Holocene large-scale meltwater discharge from Greenland documented by foraminifera and sediment parameters, Palaeogeogr. Palaeocl., 391, 71-81, 2013.

Sierro, F. J., Hodell, D. A., Curtis, J. H., Flores, J. A., Reguera, I., Colmenero-Hidalgo, E., Bárcena, M. A., Grimalt, J. O., Cacho, I., Frigola, J., and Canals, M.: Impact of iceberg melting on Mediterranean thermohaline circulation during Heinrich events, Paleoceanography, 20, PA2019, doi:10.1029/2004PA001051, 2005.

Simpson, G. L.: Analogue methods in palaeoecology: Using the analogue package, J. Stat. Soft., 22, 1-29, 2007.

Stanford, J. D., Rohling, E. J., Hunter, S. E., Roberts, A. P., Rasmussen, S. O., Bard, E., McManus, J., and Fairbanks, R. G. C. P. A.: Timing of meltwater pulse 1a and climate responses to meltwater injections, Paleoceanography, 21, PA4103, doi:10.1029/2006PA001340, 2006.

Telford, R.: palaeoSig: significance tests of quantitative palaeoenvironmental reconstructions, R Package Version, 1.1-1., 2012.

Telford, R. J., Andersson, C., Birks, H. J. B., and Juggins, S.: Biases in the estimation of transfer function prediction errors, Paleoceanography, 19, PA4014, doi:10.1029/2004PA001072, 2004.

Telford, R. J. and Birks, H. J. B.: Evaluation of transfer functions in spatially structured environments, Quaternary Sci. Rev., 28, 1309-1316, 2009.

Telford, R. J. and Birks, H. J. B.: A novel method for assessing the statistical significance of quantitative reconstructions inferred from biotic assemblages, Quaternary Sci. Rev., 30, 1272-1278, 2011.

Telford, R. J., Li, C., and Kucera, M.: Mismatch between the depth habitat of planktonic foraminifera and the calibration depth of SST transfer functions may bias reconstructions, Clim. Past, 9, 859-870, doi:10.5194/cp-9-859-2013, 2013. 
ter Braak, C. J. F. and Juggins, S.: Weighted averaging partial least squares regression (WA-PLS): an improved method for reconstructing environmental variables from species assemblages, Hydrobiologia, 269-270, 485-502, 1993.

ter Braak, C. J. F., Juggins, S., Birks, H. J. B., and van der Voet, H.: Weighted averaging partial least squares regresion (WAPLS): definition and comparison with other methods for speciesenvironment calibration, chapter 25, in: Multivariate Environmental Statistics, edited by: Patil, G. P. and Rao, C. R., Elsevier Science Publishers B.V., North-Holland, Amsterdam, 525-560, 1993.

ter Braak, C. J. F. and Prentice, I. C.: A Theory of Gradient Analysis, in: Advances in Ecological Research, edited by: Begon, M., Fitter, A. H., Ford, E. D., and Macfadyen, A., Academic Press, Volume 18, 271-317, 1988 .

Thornalley, D. J. R., Elderfield, H., and McCave, I. N.: Holocene oscillations in temperature and salinity of the surface subpolar North Atlantic, Nature, 457, 711-714, 2009.

Thornalley, D. J. R., McCave, I. N., and Elderfield, H. C. P. A.: Freshwater input and abrupt deglacial climate change in the North Atlantic, Paleoceanography, 25, PA1201, doi:10.1029/2009PA001772, 2010.

Tornqvist, T. E. and Hijma, M. P.: Links between early Holocene ice-sheet decay, sea-level rise and abrupt climate change, Nat. Geosci., 5, 601-606, 2012.
Trask, P. D.: Relation of salinity to the calcium carbonate content of marine sediments, US Geological Survey Professional Paper, 186-N, 273-299, 1936.

Wanner, H., Mercolli, L., Grosjean, M., and Ritz, S. P.: Holocene climate variability and change; a data-based review, J. Geol. Soc., 172, 254-263, 2014.

Winter, A., Jordan, R. W., and Roth, P. H.: Biogegraphy of living coccolithophores in ocean waters, in: Coccolithophores, edited by: Winter, A. and Siesser, W. G., University Press, Cambridge, 161-178, 1994.

Zazo, C., Dabrio, C. J., Goy, J. L., Lario, J., Cabero, A., Silva, P. G., Bardají, T., Mercier, N., Borja, F., and Roquero, E.: The coastal archives of the last $15 \mathrm{ka}$ in the Atlantic-Mediterranean Spanish linkage area: Sea level and climate changes, Quatern. Int., 181, 72-87, 2008

Ziveri, P., Rutten, A., de Lange, G. J., Thomson, J., and Corselli, C.: Present-day coccolith fluxes recorded in central eastern Mediterranean sediment traps and surface sediments, Palaeogeogr. Palaeocl., 158, 175-195, 2000.

Zweng, M. M., Reagan, J. R., Antonov, J. I., Locarnini, R. A., Mishonov, A. V., Boyer, T. P., Garcia, H. E., Baranova, O. K., Johnson, D. R., Seidov, D., and Biddle, M. M.: World Ocean Atlas 2013, Volume 2: Salinity, in: NOAA Atlas NESDIS 74, edited by: Levitus, S. and Mishonov, A., 39 pp., 2013. 